\title{
Implementation of Experimental Text Writing Learning in Internet Networks during the Covid-19 Period: A Case Study in Class IX of SMP Negeri 1 Kedung
}

\author{
Mohammad Khaizar Rohman ${ }^{1}$, Andayani², Suyitno ${ }^{3}$ \\ ${ }^{1,2,3}$ Universitas Sebelas Maret Surakarta, Indonesia \\ mohammad.khaizar12@student.uns.ac.id,andayani@staff.uns.ac.id,yitsuyitno52@gmail.com
}

\begin{abstract}
The purpose of this study is to describe: 1) planning for learning to write experimental texts through the internet during the COVID-19 period; 2) implementation of learning to write experimental texts through the internet; 3) obstacles in learning to write experimental texts through the internet; 4) solutions to overcome obstacles in learning to write experimental texts through the internet. This research is a qualitative research case study method with a qualitative descriptive approach. Sources of research data are: 1) informants include Indonesian language teachers and grade IX students; 2) documents include lesson plans, media, and learning materials. The sampling technique used the purposive sampling technique. Data collection techniques used are 1) interviews and 2) document analysis. The data analysis technique used is an interactive model. The results of this study were: 1) the planning of learning to write experimental texts through the internet network in class IX went well; 2) the implementation of learning to write experimental texts through the internet is well implemented; 3) The obstacles encountered are as follows: a) students are not used to or have not adapted to learning through the internet; $b$ ) the interest and motivation of students who are not used to doing learning through the internet are low; c) different levels of ability and interest among students; d) the teacher finds it difficult to give examples. 4) Solutions from the teacher are: a) the teacher motivates students to be active; $b)$ the teacher gives continuous assignments; c) conduct two-way interaction; d) teachers collaborate with teaching materials with appropriate learning media. Furthermore, the solutions from the students are: a) students actively seek to ask questions and discuss; b) students try to adapt; c) students try to learn independently; d) students always try to learn the material given by the teacher.
\end{abstract}

Keywords

learning; internet, covid-19 pandemic

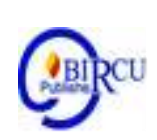

\section{Introduction}

Covid-19 (Corona Virus Disease 2019) is a contagious infectious disease that infects the lungs. Covid-19 is a dangerous virus because it can be transmitted easily through droplets (saliva liquid). With very fast transmission, Covid-19 has become a global pandemic that hampers all activities related to human interaction. One of the activities that were hampered was the teaching and learning process in schools (face-to-face learning) because it was feared as a process of transmission and spread of the virus.

The teaching and learning process in schools was changed to an online system (via the internet) to prevent the transmission and spread of Covid-19. This is done by considering the health and safety of students and educators considering the dangers of Covid-19. 
Implementation of the learning process through the internet network, of course, there are obstacles experienced due to the limitations of schools or certain areas in terms of facilities and infrastructure supporting online learning (via the internet network).

The online learning process was implemented by the government to overcome the school learning process which had been hampered and even stopped due to the Covid-19 pandemic. Online learning makes it easy for teachers and students to interact in the learning process using electronic media such as mobile phones and computers or laptops via the internet. The use of technology in electronic media has a major contribution to educational institutions, including the achievement of distance learning goals (Korucu \& Alkan, 2011). According to Moore, Dickson-Deane, and Galyen (2011), online learning is learning that uses the internet network with accessibility, connectivity, flexibility, and the ability to bring up various types of learning interactions.

Learning does not have to be done face-to-face but can be done via the internet as long as the learning objectives are achieved. Learning through the internet can be done without looking at the achievement of students' cognitive outcomes based solely on the ability to do assignments. Learning through the internet network must also go through a learning process such as teacher-student interaction and student-student interaction. By paying attention to the learning process, even though learning is carried out using an online system (via the internet) the learning objectives will still be achieved as well as face-to-face learning.

Distance learning (online) has many advantages compared to face to face learning or conventional learning. What's more during the pandemic that requires to keep distance in accordance with health protocols echoed by the government. This is reinforced by the findings of Nisa's research (2012) which states that the average learning outcomes of 1688 English students in statistical courses taught by e-learning methods have better average learning outcomes than those taught by conventional methods. Allied with these results through Santoso research (2009) which states that online learning has a greater influence than learning by using textbooks on chemistry learning achievement. Likewise, the results of Mulyani's (2013) research showed that e-learning based learning influences the learning outcomes of physics on the concepts of impulse and momentum (student learning outcomes using e-learning learning are higher than using conventional learning or face to face. (Silalahi and Hutahuruk, 2020)

Concerning learning through the internet network, the obstacles experienced by teachers or educators in the online learning process were revealed in research (Sadikin, A., \& Hakim, N., 2019). The results of the study reported that not a few students had difficulties in understanding the lecture material given online. Teaching materials are usually delivered in the form of readings that are not easily understood by students. They assume that the materials and assignments are not enough because they need a direct explanation from the lecturer. Other studies that reveal the obstacles or challenges of online learning are carried out (Astuti, P., \& Febrian, F., 2019). The research reveals the challenge of online learning is the availability of internet services. Some students access the internet using cellular services, and a few use WiFi services. When the online learning policy was implemented at Jambi University, students returned home. They have difficulty cellular signal when in their respective areas, even if there is a signal that is obtained is very weak. This is a challenge in itself in the application of online learning at Jambi University. Online learning has weaknesses when internet services are weak, and lecturer instructions are poorly understood by students (Astuti, P., \& Febrian, F., 2019).

SMP Negeri 1 Kedung which is the object of this research is a school that has implemented learning through the internet. SMP Negeri 1 Kedung can follow government 
directives to conduct learning via the internet because the facilities and infrastructure owned are sufficient to be able to organize learning activities through the internet network. Based on that, this study will discuss the process of learning to write experimental texts through the internet network at SMP Negeri 1 Kedung.

Writing is a language skill to express expressions and feelings through writing. Writing skills must be continuously trained to have good writing skills. This is following the opinion of Tarigan (2008: 4), Tarigan stated that writing skills do not come automatically but through frequent and regular practice and practice. Slamet (2008: 96) adds that continuous experience and practice can affect the quality of writing. So that writing is not a simple activity and does not need to be studied, but mastered (Slamet, 2008: 96). In the IX grade syllabus of junior high school there is one writing activity, namely writing experimental text. Based on this, researchers are interested in studying the implementation of learning to write experimental texts through the internet. This study aims to describe: 1) learning planning for writing experimental texts via the internet during the Covid-19 period in class IX students of SMP Negeri 1 Kedung; 2) implementation of learning to write experimental texts through the internet; 3) obstacles in learning to write experimental texts through the internet; 4) solutions to overcome obstacles in learning to write experimental texts through the internet.

This case study research at SMP Negeri 1 Kedung was conducted for class IX students to provide an overview of learning to write experimental texts through the internet to find out the advantages or disadvantages of the learning process. So that it can be used as an example or evaluation material for learning through the internet network.

\section{Research Methods}

This research is qualitative research with a qualitative descriptive approach. Qualitative research describes in terms of words and language a phenomenon experienced by research subjects (Moleong, 2010). This research method is case study research. Case study research examines in-depth certain events, environments, and situations that allow expressing or understanding something (Prastowo, 2011: 129). Furthermore, Prastowo (2011: 130) explains that the case study method has the following characteristics, 1) the subject under investigation consists of one unit which is seen as a case; 2) an investigation of a case is carried out intensively and in detail so that it generally produces a longitudinal picture; 3) The research result is a generalization of typical patterns of individuals, groups, institutions and so on.

The data sources for this research are: 1) informants consisting of Indonesian language teachers and grade IX students; 2) documents that include the syllabus, lesson plans (RPP), media, and learning materials consisting of learning videos and written materials delivered by the teacher. The sampling technique in this study used a purposive sampling technique. Data collection techniques used are 1) interviews; and 2) document analysis. The data analysis technique used in this study is an interactive model. The interactive model data analysis technique according to Milles and Huberman (2007: 16), consists of four stages carried out, namely 1) Data collection; 2) Data reduction; 3) Data presentation; 4) Drawing conclusions or verification stage. 


\section{Results and Discussion}

\subsection{Learning Planning for Writing Experimental Texts via the Internet}

Learning planning is an important factor that must be considered to achieve learning success. According to Savage (2014: 3), Planning is a process of thinking and arranging teaching and learning plans implemented in groups of students at a predetermined time and place. Planning is an effort made by planners to arrange the steps that will be implemented to achieve the predetermined goals (Marwiyah, Alauddin, and Ummah, 2018: 51)

Learning planning is made by the teacher which contains learning steps that are structured and systematic to achieve the learning objectives contained in the syllabus. Learning planning affects the success of learning because the learning process will be conceptualized and run according to the wishes of the teacher based on the learning objectives achieved. Without a learning plan, teachers will find it difficult and confused to organize the learning process because the learning objectives are not contained in systematic and structured learning steps. This can also result in learning not going interesting because the teacher does not think of appropriate and creative steps to make learning more interesting. Competent teachers must have the ability to plan good lessons to produce a good learning process. (Marwiyah, Alauddin, and Ummah, 2018: 51), making lesson plans or learning implementation plans (RPP) to make the learning process run effectively and efficiently; teachers can become professional educators, especially in educating and providing learning to their students; students can get good learning outcomes; planning can be used as a guide in achieving predetermined goals; learning activities can be carried out according to plan.

Based on the results of interviews and document analysis, the IX grade Indonesian teacher at SMP Negeri 1 Kedung carried out a systematic and structured learning plan as stated in the lesson plan sheet (RPP). The teacher prepares a lesson plan (RPP) based on the syllabus. The teacher also stated that he was coordinating and exchanging knowledge with the Indonesian language teacher association facilitated by the MGMP so that the learning implementation plan (RPP) that was prepared was easier to carry out and was appropriate because it had been negotiated with an association of competent Indonesian language teachers. The prepared RRP has been prepared following the conditions that must be faced by education in Indonesia, namely online learning or learning through the internet network. Based on the document analysis conducted, the lesson plans contain: basic competencies (KD); learning objectives; Learning Activities; and assessment.

The planned learning activities are following online learning, namely utilizing WhatsApp (WA) groups as a medium of communication and 2-way interaction, reference readings in the form of books or online reading resources and PPT provided via URL links, and collection of assignments through school bloggers or google classroom. The assessment contained in the lesson plan contains an attitude assessment, cognitive assessment, and skills assessment. The planned attitude assessment is a disciplined and polite attitude. The planned cognitive assessment is through a written description test. The planned skill assessment is through a performance test. The assessment planned in the RPP is equipped with an assessment rubric as a reference for the teacher to give an assessment. Based on the research conducted by the researcher, it can be concluded that the planning of learning to write experimental texts through the internet network in class IX of SMP Negeri 1 Kedung has been going well as stated in the Learning Implementation Plan made by the teacher. 


\subsection{Implementation of Experimental Text Writing Learning through the Internet}

The implementation of learning to write experimental texts through the internet can be described through the use of methods, media, teaching materials, and implementation of evaluations, as well as remedial for students who have not achieved the learning objectives. Based on the results of interviews with Indonesian class IX teachers at SMP Negeri 1 Kedung, it can be explained that the methods used are: a) the lecture method; b) discussion method; c) assignment method; and d) training methods. The lecture method is given by the teacher through materials in the form of videos and reading materials prepared by the teacher. Students are asked to observe and pay attention to the explanation of the teaching material through the video. In addition to videos, students are also given readings that have been prepared by the teacher and can be accessed via Google Classroom. Students are then asked to summarize and ask questions about the teaching material through the WA group and the teacher is in charge of answering these questions and asking other students to think so that a two-way interaction occurs. This activity can also be regarded as a discussion model.

The assignment model is seen when the teacher gives the task of summarizing the material presented by the teacher through videos and reading material for each lesson, besides that there is also an assignment of written description tests given by the teacher through WhatsApp groups for students to work on. The model of practice in learning to write experimental texts is seen when students are given an assignment at the end of the meeting to write experimental texts. The teacher will assess the student's performance and provide feedback until the students can collect the test writing assignment properly and correctly.

Based on the interviews conducted, it can be explained that the media used to adjust to the conditions that occur is learning through the internet network using WhatsApp (WA) groups and Google Classroom. WhatsApp groups are used for two-way interaction between teachers and students to start learning. The teacher provides materials and teaching materials in the form of videos or reading materials contained in the google classroom via the URL link provided in the WA group. The teacher uses the media to carry out the learning process with the desired methods to achieve the specified learning objectives.

Based on the interviews conducted, it can be explained that the assessment and evaluation carried out related to attitude assessment, cognitive assessment, and skills assessment. Attitude assessment is focused on discipline and polite attitude. Teachers can conduct attitude assessments based on interactions in WhatsApp groups and the process of submitting assignments. Cognitive assessment is given through assignments or description questions such as summarizing, paraphrasing, or explaining the contents of the reading, mentioning the characteristics of the text, studying the structure of the text, and studying linguistic elements equipped with an assessment rubric to give scores or scores for student work. Skills Assessment is given through the performance of writing a test text. The teacher assigns students to experiment to make something and then they are asked to make an outline and develop it into an experimental text. The teacher's assessment is based on the number of frameworks made to be developed into experimental texts, and the results of students' experimental texts are assessed from the accuracy of the structure, spelling writing, and the accuracy of linguistic rules.

Based on interviews conducted by teachers, remedial are flowing, meaning that remedial are given to students whose cognitive assessments and skills assessments are not appropriate continuously until students can complete tasks and perform as desired by the teacher through the assessment rubrics compiled.

Based on research conducted by researchers, it can be concluded that the implementation of learning to write experimental texts through the internet is carried out properly following the lesson plan prepared by the teacher by utilizing the right method 
according to the conditions that occur. Teachers use learning media in the form of google rooms and WhatsApp groups to support learning through the internet network that is carried out. The learning media is also used as a medium for collecting assignments and student performance which will be assessed by the teacher to achieve learning objectives.

\subsection{Barriers to Learning to Write Experimental Texts through the Internet}

Learning to write experimental texts through the internet at SMP Negeri 1 Kedung has several obstacles so that the learning objectives cannot be achieved optimally. The obstacles encountered in learning to write experimental texts through the internet network based on the results of interviews are as follows: a) students are not used to or have not adapted to learning through the internet so that there is difficulty in understanding the lessons conveyed by the teacher; b) the interest and motivation of students who are not used to doing learning through the internet is low. In addition, students quickly feel bored easily, this is evidenced by the student's response to interact and do assignments from the teacher which is sometimes slow or even unresponsive. The same opinion was also conveyed by Niemi and Kousa (2020:367) in their research, that students' learning motivation decreases during distance learning and learning loads that are too heavy have an impact on decreasing student motivation; c) the level of ability and interest between students to learn through different networks, this causes learning to be carried out sometimes with only some students; d) the teacher finds it difficult to give examples which in everyday life are easy to give to students during face-to-face meetings and difficult to make sure students have read or understood the examples given by the teacher.

\subsection{Solutions to Overcome Barriers in Learning to Write Experimental Texts via the Internet}

Based on the results of interviews, there are solutions or efforts made by teachers and students to overcome obstacles in learning to write experimental texts through the internet network for class IX students at SMP Negeri 1 Kedung. The solutions to overcome the obstacles that occur from the teacher are as follows: a) the teacher motivates students and invites students to be active in learning through the internet network; Motivation must always be given because it can encourage the achievement of the desired learning goals. This is following the opinion of Badaruddin (2015: 19), learning motivation is the energy or psychological drive of students who take an action to master something new in the form of knowledge, skills, abilities, willingness, habits, and attitudes to achieve learning goals; b) the teacher gives continuous assignments so that students continue to be active; c) conduct twoway interactions in the Whats Apps group to create active online learning; d) the teacher collaborates on teaching materials with appropriate learning media and makes the learning process more varied so that it is interesting for students and prevents students from feeling bored.

The solutions to overcome the obstacles that occur on the part of the students are as follows: a) students try to actively ask questions and discuss in learning which is carried out through WhatsApp group media; b) students try to adapt to learning through the internet network provided by the teacher; c) students try to learn independently related to teaching materials provided by the teacher by accessing teaching materials via the internet; d) students always try to learn the material given by the teacher by reading or re-understanding the teaching material given by the teacher. 


\section{Conclusion}

Based on the results and discussion of this research, it can be concluded as follows: 1) the planning of learning to write experimental texts through the internet network in class IX of SMP Negeri 1 Kedung has been going well as stated in the Learning Implementation Plan made by the teacher; 2) the implementation of learning to write experimental texts through the internet network is carried out properly following the learning implementation plan prepared by the teacher by utilizing appropriate teaching methods and media according to the conditions that occur; 3) The obstacles encountered in learning to write experimental texts through the internet are as follows: a) students are not used to or have not adapted to learning through the internet; b) the interest and motivation of students who are not used to doing learning through the internet are low. In addition, students quickly feel bored; c) the level of ability and interest between students to carry out learning through different networks; d) the teacher finds it difficult to give examples and it is difficult to make sure students have read or understood the examples given by the teacher. 4) The solutions to overcome the obstacles that occur from the teacher are as follows: a) the teacher motivates students and invites students to be active; b) the teacher gives continuous assignments so that students continue to be active; c) conducting two-way interactions in WhatsApp groups to create active online learning; d) teachers collaborate with teaching materials with appropriate learning media and make the learning process more varied.

Furthermore, solutions to overcome the obstacles that occur on the part of students are as follows: a) students try to actively ask and discuss in learning which is carried out through WhatsApp group media; b) students try to adapt to learning through the internet network provided by the teacher; c) students try to learn independently related to teaching materials provided by the teacher by accessing teaching materials via the internet; d) students always try to learn the material given by the teacher by reading or re-understanding the teaching material given by the teacher.

\section{References}

Astuti, P., \& Febrian, F. (2019). Blended Learning Syarah: Bagaimana Penerapan dan Persepsi Mahasiswa. Jurnal Gantang, 4(2), 111-119.

Badaruddin, Achmad. (2015). Peningkatan Motivasi Belajar Siswa Melalui Konseling Klasikal. Jakarta: CV Abe Kreatifindo.

Korucu, A. T., \& Alkan, A. (2011). Differences between m-learning (mobile learning) and elearning, basic terminology and usage of m-learning in education. Procedia - Social and Behavioral Sciences.

Marwiyah, St., Alauddin, dan Ummah, Muh Khaerul. (2018). Perencanaan Pembelajaran Kontemporer Berbasis Penerapan Kurikulum 2013. Yogyakarta: Deepublish.

Miles, Matthew B. and Huberman, A. Michael. (2007). Analisis Data Kualitatif: Buku Sumber tentang Metode-metode Baru. Jakarta: UI-Press.

Moleong, Lexy J. (2010). Metodologi Penelitian Kualitatif. Bandung: PT Remaja Rosdakarya.

Moore, J. L., Dickson-Deane, C., \& Galyen, K. (2011). E-Learning, online learning, and distance learning environments: Are they the same? Internet and Higher Education.

Niemi, Hannelle Marjatta dan Kousa, Paiivi. (2020). A Case Study of Students and Teachers Perceptions in a Finnish High School during the COVID Pandemic. International Journal of Technology in Educcation Science. 4 (4). 352 - 369 
Prastowo, Andi. (2011). Metode Penelitian Kualitatif dalam Perspektif Rancangan Penelitian. Jogjakarta: Ar-Ruzz Media

Sadikin, A., \& Hakim, N. (2019). Pengembangan Media E-Learning Interaktif Dalam Menyongsong Revolusi Industri 4.0 Pada Materi Ekosistem Untuk Siswa SMA. BIODIK, 5(2), 131-138.

Savage, Jonathan. (2014). Lesson Planning: Key Concepts and Skills for Teachers. London: Routledge.

Silalahi, T and Hutahuruk, A. (2020). The Application of Cooperative Learning Model during Online Learning in the Pandemic Period. Budapest International Research and Critics Institute-Journal (BIRCI-Journal). P. 1683-1691.

Slamet, St. Y. (2008). Dasar-dasar Pembelajaran Bahasa dan Sastra Indonesia di Sekolah Dasar. Surakarta: UNS Press.

Tarigan, H.G. (2008). Menulis sebagai Suatu Keterampilan Berbahasa. Bandung: Angkasa. 